\title{
Examination of coagulant additives on qualitative composition of selected thermal waters
}

\author{
Ewelina Łukasiewicz ${ }^{1, *}$, and Mariusz Rząsa ${ }^{1}$ \\ ${ }^{1}$ Department of Thermal Engineering and Industrial Facilities, Faculty of Mechanical Engineering, Opole University of \\ Technology, Poland
}

\begin{abstract}
On the territory of Poland occur rich deposits of thermal waters. Although the utilisation of these waters is continuously extending, Poland is not exploiting their full geothermal potential due to high investment costs. Thermal waters industry in Poland to date indicates operations within mainly balneology as well as recreation objectives. Higher temperature values of these waters foster a washout in the surrounding rocks resulting in a high concentration of diluted substances which must be often removed. The following study investigates thermal waters from three intakes for which coagulation processes were conducted. Research clearly shows that coagulant additives not impact on the qualitative composition of thermal water, what is very important according to medicinal properties of water. The study results may be further applied as a valuable piece of information for further exploitation in balneology or within the heating sector and other installations.
\end{abstract}

\section{Introduction}

On the territory of Poland are rich deposits of thermal waters which are gradually more exploited as a national trend. Pursuant to the provisions of the Geological and Mining Act of June, 9, 2011 (Journal of Laws of 2011, No 163 item 981) thermal water is referred to as an underwater type with a temperature exceeding $20^{\circ} \mathrm{C}$ at the outflow of the source, and it does not originate from the drainage of mine headings [1].

According to the development of the scientific Polish Geothermal Association (PGA), at least $6600 \mathrm{~km}^{2}$ of geothermal water with temperatures of $27-125{ }^{\circ} \mathrm{C}$ is accumulated within the area of Poland. These resources are present in almost all countries in certain geothermal provinces and districts. The vast majority of the area is the Polish Province of Central-European sedimentary swimming pools with geothermal water, including tanks: the Cambrian, Devonian-Carboniferous, Permian, Zechstein, Triassic, Jurassic and Cretaceous [2].

In Europe and throughout the world, water and geothermal energy are used primarily in heating systems and as domestic hot water and in individual installations, recreational ones and spa centers, in agriculture (for heating greenhouses, crops under foil cover and heating the soil). Any other uses of the thermal waters include water fish cultures, algae, industrial processes such as e.g. drying or pasteurization, melting snow and ice from sidewalks and roadways or airport runways heating. Carbon dioxide, edible salt and other chemicals can be recovered from the geothermal water. They are applied in cosmetics production or they are bottled as a curative and mineral [3] supplement. Frequently, the geothermal water can be used as the drinking type of water [4]. The pores, cracks, fissures and fault rocks of the Earth's crust also contain the geothermal waters. In Poland, geothermal waters (or thermal types) are characteristic for their temperature exceeding $20^{\circ} \mathrm{C}$. With regard to the fact that in Poland the geothermal waters are exploited in balneology and recreation sectors, their quality shall comply with the limit values specified in the Regulation of the Minister of Health dated November 9, 2015 concerning the requirements to be fulfilled by the swimming pool water [5]. The selected physico chemical requirements to be fulfilled by the swimming pool water are presented in the Table 1 .

Table 1. Selected physico-chemical requirements to be fulfilled by the water in the swimming pools [5].

\begin{tabular}{|c|c|c|c|c|c|}
\hline \multirow[t]{2}{*}{ Parameter } & \multirow[t]{2}{*}{ Unit } & \multicolumn{2}{|c|}{$\begin{array}{l}\text { Water supplied } \\
\text { into a swimming } \\
\text { pool basin from the } \\
\text { circulation system }\end{array}$} & \multicolumn{2}{|c|}{$\begin{array}{c}\text { Water inside } \\
\text { the swimming } \\
\text { pool basin }\end{array}$} \\
\hline & & $\min$ & $\max$ & $\min$ & $\max$ \\
\hline $\begin{array}{l}\mathrm{pH} \text { of fresh } \\
\text { water }\end{array}$ & & 6.5 & 7.6 & 6.5 & 7.6 \\
\hline $\begin{array}{c}\mathrm{pH} \\
\text { of salt water }\end{array}$ & & 6.5 & 7.8 & 6.5 & 7.8 \\
\hline turbidity & NTU & - & 0.3 & - & 0.5 \\
\hline aluminium & $\mathrm{mg} / \mathrm{L}$ & & - & & 0.2 \\
\hline total iron & $\mathrm{mg} / \mathrm{L}$ & & - & & 0.2 \\
\hline nitrates & $\mathrm{mg} / \mathrm{L}$ & & 20 & - & 20 \\
\hline oxidisability & $\mathrm{mg} / \mathrm{L}$ & - & - & - & 4 \\
\hline
\end{tabular}

* Corresponding author: e.lukasiewicz@po.opole.pl 
The thermal water in the intake frequently does not fulfil such requirements, therefore it shall be subjected to the purification process. Coagulation is one of the purification methods concerning waters with an increased level of iron and manganium content $[6,7]$.

\section{Coagulation}

Coagulation is a process commonly applied for removal of the surface colloidal contaminants both of organic and inorganic origin as well as hardly falling suspensions. It is dramatically important to assure high effectiveness of coagulation due to its further purification stages. It results from a possibility of diminishing a demand for application of oxidising agents or disinfectants.

A non-hydrolised aluminium sulphate (VI) $\mathrm{Al}_{2}\left(\mathrm{SO}_{4}\right)_{3}$ belongs to one of the most widely used coagulants in the Polish water treatment plants. However, it is more frequently substituted with the initially hydrolised coagulants which respond with increased efficiency to the removal of organic contaminants, disintegration of colloids with negative electric charge and disinfectants causing water turbidity. Moreover, they display greater resilience to the temperature as well as $\mathrm{pH}$ values fluctuations. The initially hydrolised coagulants include polyaluminium chlorides and sulphates. The increased values of alkalinity among such types of substances arise from the presence of hydroxyl groups. The alkalinity indicator serves as a polymerisation degree measure $[7,8]$.

The thermal water composition is very diverse as a consequence of a contact with rocks and minerals and a high degree of salinity. Before using such water in the geothermal systems and heat exchangers it must undergo a process of purification. The process of removing iron ions seems to be of key importance here. The most common forms of the iron element are hydrogen carbonate, iron (II) sulphate or iron (IV) sulphate. For the sake of insoluble forms precipitation of iron hydroxide, $\mathrm{Fe}(\mathrm{OH})_{3}$ and methods such as aeration, liming and coagulation $[9,10,11]$ are commonly applied. The suspended substances referred to as colloidal reveal such common features as a small size, a large surface area and a relatively high electric charge of particles. A destabilization of a colloidal system is often possible only due to a chemical treatment.

\section{Methodology}

The objective of the following research is assessment of the coagulation process in the course of de-ironing of the thermal waters as well as determination of the coagulant additive impact on the ionic water content. Here, the coagulation process was performed with the use of initially hydrolised aluminium coagulants known under the trading names as Flokor 1,2A and Flokor DM17H. The selected physico-chemical data of the applied coagulants is plotted in the Table 2 . The quality analysis was exerted on the water from three thermal water intakes: Uniejów, Wołczyn and Lądek-Zdrój. In
Uniejów, the water temperature at the level of intake is $68^{\circ} \mathrm{C}$, in Wołczyn it reaches $37^{\circ} \mathrm{C}$, and in Ladek-Zdrój it is as high as $44^{\circ} \mathrm{C}$. The source of Uniejów intake water is PIG/AGH-2 drilling well and this water fulfils the criteria of mineral healing water $0.63 \%$ chloro - sodium, hiperthermal water. Thus, it may be used either for bathing or for supplementary drinking treatment.

Table 2. Physico - chemical data of the applied coagulants.

\begin{tabular}{|c|c|c|}
\hline \multirow{2}{*}{ State } & Flokor 1,2A & Flokor DM17H \\
\cline { 2 - 3 } & $\begin{array}{c}\text { light grey or } \\
\text { transparent liquid }\end{array}$ & $\begin{array}{l}\text { light grey } \\
\text { or transparent } \\
\text { liquid }\end{array}$ \\
\hline $\begin{array}{c}\text { Turbidity in } 20^{\circ} \mathrm{C} \\
{\left[\mathrm{g} / \mathrm{cm}^{3}\right]}\end{array}$ & $1.290 \pm 0.05$ & $1.275 \pm 0.05$ \\
\hline $\mathrm{pH}$ & $4.20 \pm 0.50$ & $3.50 \pm 0.50$ \\
\hline $\begin{array}{c}\mathrm{Aluminium} \mathrm{Al}^{3+} \\
{[\%]}\end{array}$ & $12.00 \pm 0.50$ & $8.50 \pm 0.50$ \\
\hline $\mathrm{Al}_{2} \mathrm{O}_{3}[\%]$ & $22.60 \pm 0.90$ & $16.00 \pm 0.90$ \\
\hline Chlorides $\mathrm{Cl}-[\%]$ & $6.50 \pm 0.50$ & $7.50 \pm 0.50$ \\
\hline Alkalinity [\%] & $85.00 \pm 5.00$ & $75.00 \pm 5.00$ \\
\hline $\begin{array}{c}\text { Solidification } \\
\text { temperature }\left[{ }^{\circ} \mathrm{C}\right]\end{array}$ & about $-5^{\circ} \mathrm{C}$ & about $-22^{\circ} \mathrm{C}$ \\
\hline
\end{tabular}

Geotermia Uniejów Partnership was founded in Q3 of 1999 under the initiative of Uniejów Municipality as well as the Provincial Environmental Protection and Water Management Fund in Łódź. The distribution of heat to the recipients began in September 2001. 180 power connections have been established till the present date, out of which 30 are connections with a large - scale customers who collect $80 \%$ of the total amount of the heat output. The total heating plant power is $5.6 \mathrm{MWt}$, out of which $3.2 \mathrm{MWt}$ is generated by the geothermal spring and 2.4 MWt originates from the peak-load source basing on two oil-fuelled boiler stations.

The water from Wołczyn intake comes from a VII A drilling well and possesses $23.3 \mathrm{~g} / \mathrm{dm}^{3}$ of solids. It is a chloride-sodium-calcium-bromide bringe also rich in iron and boron. It may be successfully applied either for bathing or for inhalations. So far, the waters have not been covered by any investment.

Lądek-Zdrój water is extracted from L-2 „Zdzisław” drilling well and sulphide-fluoride baths are among its principal applications.

The waters from Wołczyn and Uniejów revealed an increased colour intensity as well as iron and manganium content, thus they were subjected to removal with the use of a coagulant additive. Lądek-Zdrój water did not require any treatment and therefore the only experimental studies were led for this water to verify the interplay of a coagulant additive with the ionic water content.

Tests on iron, manganium and aluminium content were performed with a spectrophotometric method with the use of a UV-VIS spectrophotometer. The ionic analysis was run with the use of a IC chromatograph. $\mathrm{Ph}$ metry was done in accordance with PN-90 C-04540/01 norm [12], conductivity test - PN-EN 27888 norm [13], colour test - PN-EN ISO 7887 norm [14], turbidity test PN-EN ISO 7027 norm [15]. The volume coagulation was conducted in the ambient temperature 
and within the first 24 hours since the collection time of water samples.

The study results presented beneath are divided according to the three intakes. Uniejów water was subjected to coagulation with the use of Flokor 1,2A in the following doses: 10,20 and $40 \mathrm{~g} / \mathrm{m}^{3}$. Wołczyn water underwent coagulation with the use of Flokor 1,2A and Flokor DM17H, in the following doses: 10, 20, 50 and $100 \mathrm{~g} / \mathrm{m}^{3}$ and $30 \mathrm{~g} / \mathrm{m}^{3}$, respectively. The water sample was also submitted for the ionic analysis. Lądek- Zdrój water was not prone for treatment and in this case the impact assessment was run exclusively of the coagulant additive against the ionic water content. Flokor 1,2 A coagulant was submitted in a dose of $40 \mathrm{~g} / \mathrm{m}^{3}$.

\section{Results and discussion}

\subsection{Thermal water - Uniejów}

Table 3 is a collection of the test results for Uniejów water. This water is characterised with an increased colour intensity and iron content. Consequently, the coagulation was arranged with the use of Flokor 1,2A in the following doses: $10 \mathrm{~g} / \mathrm{m}^{3}, 20 \mathrm{~g} / \mathrm{m}^{3}$ and $40 \mathrm{~g} / \mathrm{m}^{3}$. Ionic analysis was not carried out for this water.

Table 3. Quality of Uniejów water intake.

\begin{tabular}{|c|c|c|c|c|c|}
\hline \multirow{2}{*}{ Index } & \multirow{2}{*}{ Unit } & \multirow{2}{*}{ Raw } & \multicolumn{4}{|c|}{ Wlokor 1,2A doses } \\
\cline { 4 - 6 } & & & $\mathbf{1 0 g} / \mathbf{m}^{\mathbf{3}}$ & $\mathbf{2 0 g} / \mathbf{m}^{3}$ & $\mathbf{4 0 g} / \mathbf{m}^{3}$ \\
\hline $\mathrm{pH}$ & & 7.18 & 7.22 & 7.25 & 7.24 \\
\hline$\sigma$ & $\begin{array}{c}\mathrm{mS} / \mathrm{c} \\
\mathrm{m}\end{array}$ & 11.57 & 11.58 & 11.63 & 11.61 \\
\hline $\begin{array}{c}\text { Total } \\
\mathrm{Fe}\end{array}$ & $\mathrm{mg} / \mathrm{L}$ & 0.418 & 0.110 & 0.0246 & 0.0057 \\
\hline $\mathrm{Mn}$ & $\mathrm{mg} / \mathrm{L}$ & 0.128 & 0.0623 & 0.0563 & 0.0552 \\
\hline Colour & $\begin{array}{c}\mathrm{mg} \\
\mathrm{Pt} / \mathrm{L}\end{array}$ & 34 & 6 & 4 & 2 \\
\hline
\end{tabular}

\subsection{Thermal water - Wołczyn}

The desired testing was performed on the raw water subjected to coagulation and Flokor 1,2 A coagulant in doses of 20 and $50 \mathrm{~g} / \mathrm{m}^{3}$ and Flokor DM17H in a dose of $30 \mathrm{~g} / \mathrm{m}^{3}$ (Table 4 and Table 5).

Table 4. Anions concentration in water intake of Wołczyn.

\begin{tabular}{|c|c|c|c|c|}
\hline $\begin{array}{c}\text { Peak } \\
\text { name }\end{array}$ & Raw & $\begin{array}{c}\mathbf{2 0 g} / \mathbf{m}^{\mathbf{3}} \\
\mathbf{1 , 2 A}\end{array}$ & $\begin{array}{c}\mathbf{5 0 g} / \mathbf{m}^{\mathbf{3}} \\
\mathbf{1 , 2 A}\end{array}$ & $\begin{array}{c}\mathbf{3 0 g} / \mathbf{m}^{\mathbf{3}} \\
\mathbf{D M 1 7 H}\end{array}$ \\
\hline & {$[\mathrm{mg} / \mathrm{L}]$} & {$[\mathrm{mg} / \mathrm{L}]$} & {$[\mathrm{mg} / \mathrm{L}]$} & {$[\mathrm{mg} / \mathrm{L}]$} \\
\hline Chlorides & 14,850 & 14,750 & 15040 & 15594 \\
\hline Bromides & 76.38 & 78.62 & 78.84 & 76.75 \\
\hline Sulphates & 2573.1 & 2597.4 & 2629.5 & 2641.9 \\
\hline
\end{tabular}

Table 5. Cations concentration in water intake of Wołczyn.

\begin{tabular}{|c|c|c|c|c|}
\hline Peak name & Raw & $\begin{array}{c}\mathbf{2 0 g} / \mathbf{m}^{\mathbf{3}} \\
\mathbf{1 , 2 A}\end{array}$ & $\begin{array}{c}\mathbf{5 0 g} / \mathbf{m}^{\mathbf{3}} \\
\mathbf{1 , 2 A}\end{array}$ & $\begin{array}{c}\mathbf{3 0 g} / \mathbf{m}^{\mathbf{3}} \\
\mathbf{D M 1 7 H}\end{array}$ \\
\hline Lithium & 6.39 & 6.35 & 6.46 & 6.70 \\
\hline Sodium & 8300 & 8250 & 8410 & 8690 \\
\hline Ammonium & 6.8 & 6.87 & 7.35 & 6.95 \\
\hline Magnesium & 369.4 & 367.9 & 374.1 & 388.9 \\
\hline Calcium & 1850 & 1911 & 1870 & 1950 \\
\hline
\end{tabular}

The temperature in the intake was $37{ }^{\circ} \mathrm{C}$. The ionic analysis was carried out and the coagulant additive was evaluated according to its impact on the ionic content of water .

In accordance with Pourbaix's graph, i.e. the graph of potential/pH for the iron compounds, the solid forms of iron occur when the medium reaches $\mathrm{pH}$ values of $>7$. The tests performed for the model waters with increased salinity and temperatures indicated that the applied coagulants accrue the highest effectiveness levels (deironing) within the $\mathrm{pH}$ range of $7.9-8.1[5,9]$.

Due to the fact that the water sample had a $\mathrm{pH}=6.51$, it was essential to increase the $\mathrm{pH}$ level up to the required range (Table 6).

Table 6. Quality of Wołczyn water intake.

\begin{tabular}{|c|c|c|c|c|c|c|}
\hline Index & Raw & $\begin{array}{c}\text { DM17 } \\
\mathrm{H} \\
\mathbf{3 0} \mathrm{g} / \mathrm{m}^{3}\end{array}$ & $\begin{array}{l}1,2 \mathrm{~A} \\
10 \mathrm{~g} / \mathrm{m}^{3}\end{array}$ & $\begin{array}{c}1,2 \mathrm{~A} \\
20 \mathrm{~g} / \mathrm{m}^{3}\end{array}$ & $\begin{array}{l}1,2 \mathrm{~A} \\
50 \mathrm{~g} / \mathrm{m}^{3}\end{array}$ & $\begin{array}{c}1,2 \mathrm{~A} \\
100 \\
\mathrm{~g} / \mathrm{m}^{3}\end{array}$ \\
\hline $\mathrm{pH}$ & 6.51 & 7.28 & - & 7.16 & 7.31 & - \\
\hline $\begin{array}{c}\sigma \\
\mathrm{mS} / \mathrm{cm}\end{array}$ & 42.9 & 43.00 & - & 43.10 & 43.11 & - \\
\hline $\begin{array}{c}\text { Total } \\
\text { Fe } \\
\text { (decant } \\
\text { ate) } \\
\mathrm{mg} / \mathrm{L}\end{array}$ & 1.42 & 0.927 & 22.50 & 0.847 & 0.891 & 21.60 \\
\hline $\begin{array}{l}\text { Total } \\
\text { Fe } \\
\text { (filtra- } \\
\text { te) } \\
\mathrm{mg} / \mathrm{L}\end{array}$ & 0.80 & 0.006 & $<0.005$ & $<0.005$ & $<0.005$ & $<0.005$ \\
\hline $\begin{array}{c}\mathrm{Mn} \\
\text { (filtra- } \\
\text { te) } \\
\mathrm{mg} / \mathrm{L}\end{array}$ & 1.13 & 1.09 & - & 1.08 & 1.04 & - \\
\hline $\begin{array}{c}\text { Colour } \\
\text { (deca- } \\
\text { ntate) } \\
\mathrm{mg} \mathrm{Pt} / \mathrm{L}\end{array}$ & 94 & 58 & - & 54 & 22.50 & - \\
\hline $\begin{array}{c}\text { Colour } \\
\text { (filtra- } \\
\text { te) } \\
\mathrm{mg} \mathrm{Pt} / \mathrm{L}\end{array}$ & 2 & 2 & - & 2 & 2 & - \\
\hline
\end{tabular}

The amendment of $\mathrm{pH}$ was generated with the use of $0.1 \mathrm{~m} \mathrm{NaOH}$. Wołczyn intake water was yellowishbrown in colour $>1000 \mathrm{mg} \mathrm{Pt} / \mathrm{dm}^{3}$, thereby it shall 
become less intensive. Moreover, it included an increased amount of total iron i.e. $65,30 \mathrm{mg} / \mathrm{dm}^{3}$.

\subsection{Thermal water - Lądek Zdrój}

The water in Lądek-Zdrój is reveals a high quality what is manifested by its determination as potable water, thus it has not required any treatment. The ionic analysis for that water was presented below. For the sake of the investigation and control, it was decided to conduct coagulation in order to assess the impact of a coagulant aluminium additive on the content of water. (Table 7 and Table 8).

Table 7. Cations concentration in water intake of Lądek-Zdrój.

\begin{tabular}{|c|c|c|}
\hline Peak name & Raw & $\mathbf{4 0} \mathbf{g} / \mathbf{m}^{\mathbf{3}} \mathbf{1 , 2 A}$ \\
\hline & {$[\mathrm{mg} / \mathrm{L}]$} & {$[\mathrm{mg} / \mathrm{L}]$} \\
\hline Lithium & 0.0257 & 0.0267 \\
\hline Sodium & 49.1891 & 50.7335 \\
\hline Potassium & 0.7197 & 0.7859 \\
\hline Calcium & 3.0555 & 2.3571 \\
\hline
\end{tabular}

Table 8. Anions concentration in water intake of Lądek Zdrój.

\begin{tabular}{|c|c|c|}
\hline Peak name & Raw & $\mathbf{4 0} \mathbf{g} / \mathbf{m}^{\mathbf{3}} \mathbf{1 , 2 A}$ \\
\hline & {$[\mathrm{mg} / \mathrm{L}]$} & {$[\mathrm{mg} / \mathrm{L}]$} \\
\hline fluorides & 10.7757 & 10.7655 \\
\hline chlorides & 5.1649 & 12.0046 \\
\hline bromides & 0.0339 & 0.0363 \\
\hline nitrates & - & 0.0174 \\
\hline phosphates & 0.4807 & 0.4169 \\
\hline sulphates & 19.4341 & 19.9799 \\
\hline
\end{tabular}

\section{Conclusions}

Uniejów intake water is characterised with an increased level of iron content, in raw water its content equals $0.418 \mathrm{mg} / \mathrm{L}$. Even the lowest dose of Flokor 1,2 A, i.e. $10 \mathrm{~g} / \mathrm{m}^{3}$ enabled one to reduce its content up to 0.110 $\mathrm{mg} / \mathrm{dm}^{3}$, thus the norm $0.2 \mathrm{mg} / \mathrm{dm}^{3}$ was ensured. The colour intensity and turbidity were heavily reduced, however it shall be here highlighted that in case of the thermal waters and healing or mineral waters, the colour is induced by the desired components of these waters. Taking the potable waters into account, their colour intensity and turbidity shall stay at a consumeracceptable level and they shall be devoid of any inappropriate alterations. The coagulant developed as a result of reduction of the total iron as well as manganium amount, it also decreased the colour intensity and turbidity up to the quality norms for the potable water (Journal of Laws 2015, item 1989).

Considering the water from Wołczyn, a coagulant additive has not affected significantly the ionic content of water. In this case, chlorides content constituted a value which rose substantially i.e. by circa 0.75 grams for Flokor DM17H and a dose of $30 \mathrm{~g} / \mathrm{m}^{3}$. De-ironing with the use of both Flokor 1.2A and DM17H resulted in a satisfactory outcome. The iron content in a decanter dropped by circa 99\%. Flokor 1,2A doses, i.e. 10 and $100 \mathrm{~g} / \mathrm{m}^{3}$ have not caused any dramatic reduction of the total iron amount. The amount of manganium compounds has not been reduced. The filtration ensured a high degree of colour intensity decrease - up to $2 \mathrm{mg}$ $\mathrm{Pt} / \mathrm{dm}^{3}$. Lądek-Zdrój water ionic content has not undergone a substantial modification after submitting it with a coagulant. The only parameter where an ample difference might be noticed concerns chlorides as their content more than doubled.

Prior to application of the thermal waters in balneology, water treatment is not essential due to a high value of medicinal effects of such waters. Nevertheless, in the heating sector and energetics that is in installations where e.g. heat exchangers would be applied, water treatment would also be necessary as the compounds might be responsible for the encrustation of pipes, corrosion or other technological issues.

\section{References}

1. Act from 9 June 2011 Geological and Mining Law (Journal of Laws 2011 No. 163 Item 981)

2. A. Zimny, M. Karch, K. Szczotka, PGA, Kraków (2008) www.pga.org.pl (in Polish)

3. Y. Noorollahi, H. Y. Sahzabi, Proceedings World Geothermal Congress (2005)

4. B. Kępińska, Przegląd Geologiczny 58, 7 (2010)

5. Regulation of the Minister of Health dated November 9, 2015 concerning the requirements to be fulfilled by the swimming pool water (Journal of Laws of 2015, item 2016)

6. A. Nowacka, M. Włodarczyk-Makuła, Ann. Set Environ. Prot. 16 (2014)

7. E. Podgórni, M. R. Rząsa, Pol. J. Environ. Stud. 23, 6 (2014)

8. J. Gumińska, M. Kłos, Gaz, woda i technika sanitarna 5, 195 (2011)

9. H. Alçiçek, A. Bülbül, M. C. Alçiçek, J. Volcanol. Geotherm Res. 309 (2016)

10. M. Goosen, H. Mahmoudi, N. Ghaffour, Energies 3 (2010)

11. Z. Zięba, E. Grzesiak, Infrast. Ecol. Rural Areas 8, 1 (2010)

12. Electrometric determination of $\mathrm{pH}$ in water and wastewater having the electrolytic conductivity of 10 microsimens/cm and above: Polish Standard PN90/C-04540/01

13. Determination of electrolytic conductivity: Polish Standard PN-EN 27888:1999

14. Examination and determination of colour (ISO 7887:2011)

15. Determination of turbidity - Part 1: Quantitative methods (ISO 7027-1:2016) 